\title{
Growth and Trend in Area, Production and Yield of Major Crops of Bangladesh
}

\author{
Sharmin Akhter ${ }^{1}$, Jaba Rani Sarker ${ }^{2, *}$, Keya Rani Das ${ }^{3}$ \\ ${ }^{1}$ Department of Development and Poverty Studies, Sher-e-Bangla Agricultural University, Sher-e-Bangla Nagar, Dhaka, Bangladesh \\ ${ }^{2}$ Department of Agricultural Economics, Bangabandhu Sheikh Mujibur Rahman Agricultural University, Gazipur, Bangladesh \\ ${ }^{3}$ Department of Statistics, Bangabandhu Sheikh Mujibur Rahman Agricultural University, Gazipur, Bangladesh
}

Email address:

sharmin_bau15@yahoo.com (S. Akhter),jrsbsmrau@gmail.com (J. R. Sarker), keyadas57@bsmrau.edu.bd (K. R. Das)

\section{To cite this article:}

Sharmin Akhter, Jaba Rani Sarker, Keya Rani Das. Growth and Trend in Area, Production and Yield of Major Crops of Bangladesh. International Journal of Economics, Finance and Management Sciences. Vol. 4, No. 1, 2016, pp. 20-25. doi: 10.11648/j.ijefm.20160401.13

\begin{abstract}
The present study was conducted with a view to analyze growth and trend in area, production and yield of major crops of Bangladesh. The scope of this study was to determine/ assess the growth pattern in the context of total cultivable area, gross production and yield rate which has been followed by some economically important crops of our country such as rice, wheat, pulse, rape and mustard, jute, sugarcane \& tea. Collecting time series data from 1969-74 to $2004-2009$ (40 years) of those crops from reliable source and using semi-log trend function here the researchers tried to find out the trend and estimate the growth rate of area, production and yield of the above mentioned crops. The compound growth rate as well as trend analysis indicated that the production of rice during 1969-74 to 2004-09 was increased due to the corresponding increase in per hectare yield of rice crop in Bangladesh. The results show that area, production and yield of wheat was increased over the time the reason is that more area was brought under wheat production except the year 2004-2009. It was revealed from the results that area, production and yield of pulse were increased over the time. The results shows that area, production and yield of rape and mustard was increasing a rate of 1.21 percent, 2.33 percent and 1.11 percent per annum, respectively, whereas, the area, production and yield of jute was decreasing. It was revealed from the analysis that the trend co-efficient of area, production and yield of sugarcane and tea was positive.
\end{abstract}

Keywords: Growth, Trend, Semi-Log Model, Major Crops, Bangladesh

\section{Introduction}

Land is one of the most important factors of production. But due to the decreasing trend of agricultural land, the yield can only increase if other factors change. Schultz (1964) considers the traditional economic structure as the main hindrance to its growth. Bangladesh is a labour-surplus country. In this case, increase in agricultural yield is possible, if agricultural practice transformed from the traditional structure. Two types of transformation are needed for increasing agricultural yield. One is technological change and the other is institutional change. The population of Bangladesh is increasing very rapidly. In this situation, to maintain food security, increase in agricultural yield is a crying demand. Under these situations, this study deals with the growth and trend in area, production, yield of major crops of Bangladesh.

In spite of the significant increase in rice production,
Bangladesh is still one of the largest food grain importers in the world. Not only this, but also we import palm oil, wheat, sugar, fruit and vegetables in large quantities. On the other hand, Jute, tobacco and tea are the leading agricultural export items of our country. Bangladesh is still the largest global exporter of jute. In the context of agriculture, cropping intensity, by the side of cropping pattern, plays the significant role in production system since the cultivable land areas have endlessly been decreasing. Such constant diminution in cultivable land has been exerting undesirable impact on the growth in agricultural sector, resulting in recent declining growth in the sector, according to the law of marginal diminishing return. Per capita agricultural land came down to 0.056 hectare in 2011 from 0.17 hectare in 1961. Rapid population growth, along with unplanned urbanization, causes the areas of cultivable land to be used for non-agricultural purpose, especially for building residence for increasing population. Statistics suggest that between the periods from 1961 to 2007, the agriculture experienced a twofold reduction 
in the availability of cultivable land. Production during this period increased due mainly to the use of input by the farmers at a higher rate on the same piece of land. For instance, one metric ton of food was produced from 0.406 hectare of land in 1961, whereas same production was achieved from the land below 0.14 hectare in 2007 (Basak, 2012).

This study was conducted to observe the growth of production of the above mentioned crops over the years whether it is significant or not. Additionally it was intended to observe the pattern of growth of these crops over time whether it has used the endowments efficiently to achieve the maximum/ optimum production. As these crops play very important role for the betterment of our economy, the study has tried to find the lapses in the part of Government's Policy supports as well as in the part of individuals'/ farmers' initiatives where insufficient growth has been experienced. Finally, the research work has tried to draw some policy recommendation to all stakeholders to acquire the intended growth to achieve the desired outcome/ optimum level of production of these economically important crops.

The specific objectives of the study are:

a) To study the present condition of agriculture in general, we have to examine the agricultural output per unit of land in Bangladesh.

b) To examine the growth and trends in area, production and yield of agricultural land of Bangladesh for the period from1969-74 to 2004-09.

\section{Materials and Methods}

The data used for the analysis are accumulated from various issues of statistics department of Bangladesh Bank. A time series data from 1969-74 to 2004-2009 (40 years) regarding the area, production and yield of major crops (rice, wheat, pulse, rape and mustard) were collected from the above mentioned source. The following semi-log trend function was used to find out the trend and estimate the growth rate of area, production and yield of major crops of Bangladesh.

$$
\ln Z=\beta_{0}+\beta_{1} X+\mathrm{e}
$$

Where $Z=$ dependent variable (area, yield and production); $X=$ trend over specific period; $\beta_{1}=$ coefficient of trend; $\ln =$ natural logarithm; and $e=$ error term. Here, the coefficient of trend $\left(\beta_{1}\right)$ measures the constant proportional or relative change in $Z$ for a given absolute change in the value of the regressor $\mathrm{X}$. If 100 multiply the relative change in $\mathrm{Z}$, give the percentage change, or the growth rate, in $Z$ for an absolute change in $X$, the regressor. That is, 100 times $\beta_{1}$ gives the growth rate in $Z ; 100$ times $\beta_{1}$ is known in the literature as the semi-elasticity of $Z$ with respect to $X$ and gives the instantaneous (at a point in time) rate of growth, to find out the compound (over a period of time) rate of growth, the following formula was applied.

$$
\beta_{1}=\ln (1+r)
$$

Where $\beta_{1}=$ Instantaneous rate of growth; $\ln =$ Natural logarithm; $r=$ Compound rate of growth. Hence taking antilog of $\beta_{1}$, subtract 1 from it and multiply the difference by 100 , would give compound rate of growth.

\section{Results and Discussion}

\subsection{Trend and Rate of Growth in Rice Crop of Bangladesh}

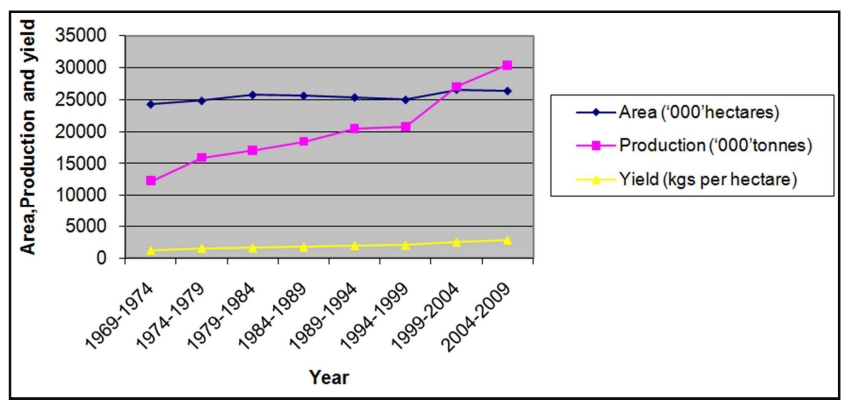

Source: Statistics department, Bangladesh Bank.

Figure 1. Trend and rate of growth in area, production and yield of rice in Bangladesh, 1969-2009.

Figure 1 indicates that during 1969-74, the area under rice crop in Bangladesh was 24232 thousand hectares as compared to 26356 thousand hectares sown during 2004-09, which shows that area of rice crop increased over time. The production of rice during 1969-74 to 29004-09 was increased from 12203 thousand tones to 30438 due to the corresponding increase in per hectare yield of rice crop in Bangladesh.

Table 1. Trend and rate of growth in area, production and yield of rice in Bangladesh, 1969-2009.

\begin{tabular}{llll}
\hline Particulars & Area & Production & Yield \\
\hline F-statistic & $9.29 * *$ & $121.37 * * *$ & $160.92^{* * *}$ \\
Trend coefficient & 0.002 & 0.023 & 0.021 \\
t-statistic & $3.047^{* *}$ & $11.02 * * *$ & $12.685^{* * *}$ \\
Instantaneous growth rate (\%) & 0.20 & 2.30 & 2.10 \\
Compound growth rate (\%) & 0.20 & 2.32 & 2.12 \\
\hline
\end{tabular}

***Significant at 1 percent level of significance **Significant at 5 percent level of significance.

The results of semi-log model for area, production and yield of rice crop during 1969-74 to 2004-09 were presented in table 1. The results of F-static show that the models were significant for area, production and yield of rice crop in Bangladesh. It was revealed from the results that trend co-efficient for rice area, production and yield was positive. The positive sign of compound growth rate shows that area, production and yield of rice crop was increasing at a rate of 0.20 percent, 2.32 percent and 2.12 percent per annum respectively.

\subsection{Trend and Rate of Growth in Wheat Crop of Bangladesh}

Wheat is the most important winter crop. The area under wheat crop in Bangladesh was increased from 304.60 thousand hectares to 1826.20 thousand hectares during 1969- 
74 to 2004 and then decreased. The production of wheat during the same period was also increased from 5677 thousand tones to 12622 thousand tones due to the corresponding increase in area except the period during 2004-2009.

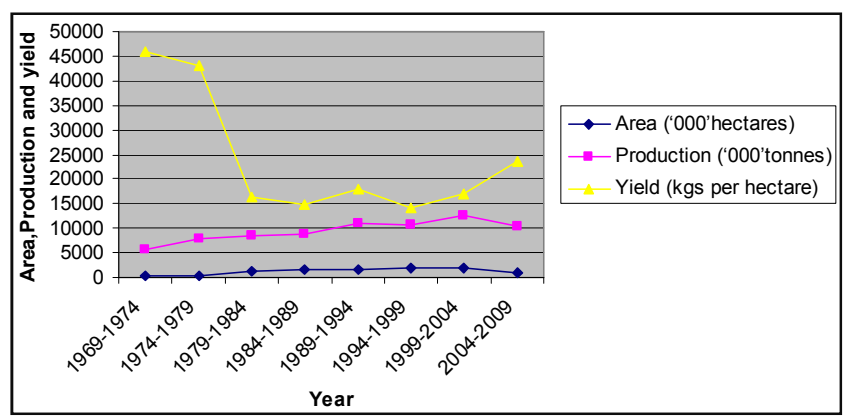

Source: Statistics department, Bangladesh Bank.

Figure 2. Trend in area, production and yield of wheat in Bangladesh, 19692009.

Table 2. Trend and rate of growth in area, production and yield of wheat in Bangladesh, 1969-2009.

\begin{tabular}{llll}
\hline Particulars & Area & Production & Yield \\
\hline F-statistic & $7.37^{* *}$ & $22.64^{* * *}$ & $3.24^{\mathrm{NS}}$ \\
Trend coefficient & 0.041 & 0.018 & -0.023 \\
t-statistic & $2.71^{* *}$ & $4.76^{* * *}$ & $-1.79^{\mathrm{NS}}$ \\
Instantaneous growth rate (\%) & 4.10 & 1.80 & -2.3 \\
Compound growth rate (\%) & 4.19 & 1.82 & -2.33 \\
\hline
\end{tabular}

***Significant at 1 percent level of significance **Significant at 5 percent level of significance and NS $=$ Not significant.

The results of semi-log model for area, production and yield of wheat crop were presented in Table 2. The results of F-statistic show that the models were significant for area and production of wheat crop whereas model for wheat yield was statistically non-significant. It was revealed from the table that trend co-efficient for wheat area and production was positive except yield which was negative. The positive sign of compound growth rate shows that area and production of wheat crop was increasing at a rate of 4.19 percent and 1.82 percent per annum. The compound growth rate during this period in yield was -2.33 percent.

\subsection{Trend and Rate of Growth in Pulse of Bangladesh}

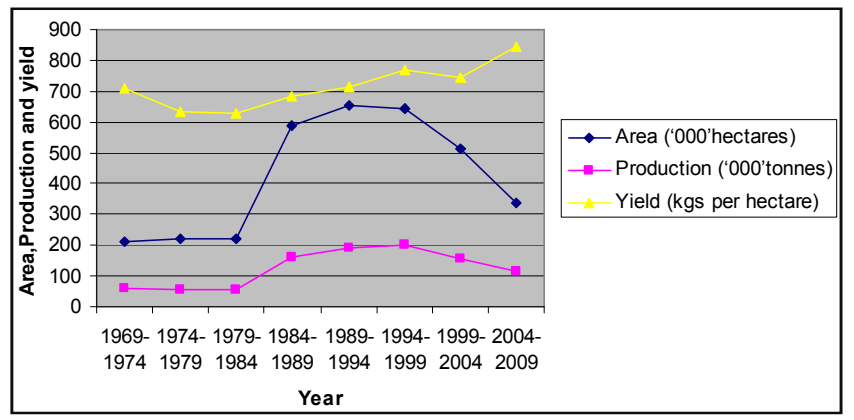

Source: Statistics department, Bangladesh Bank.

Figure 3. Trend in area, production and yield of pulse in Bangladesh, 19692009.
Figure 3 indicates that pulse was planted in Bangladesh in 1969-74 on an area of 212.4 thousand hectares with production of 61 thousand tones and yields $709.37 \mathrm{~kg}$ per hectare. In the year 2004-09 the pulse area was increased to 339.2 thousand hectares with an annual production of 115.8 thousand tones and yield $843.24 \mathrm{kgs}$ per hectare.

Table 3. Trend and rate of growth in area, production and yield of pulse in Bangladesh, 1969-2009.

\begin{tabular}{llll}
\hline Particulars & Area & Production & Yield \\
\hline F-statistic & $3.79^{*}$ & $5.93^{*}$ & $10.006^{* *}$ \\
Trend coefficient & 0.026 & 0.032 & 0.006 \\
t-statistic & $1.95^{*}$ & $2.44^{*}$ & $3.16^{* *}$ \\
$\begin{array}{l}\text { Instantaneous growth } \\
\text { rate (\%) }\end{array}$ & 2.60 & 3.20 & 0.60 \\
$\begin{array}{l}\text { Compound growth } \\
\text { rate (\%) }\end{array}$ & 2.63 & 3.25 & 0.60 \\
\hline
\end{tabular}

*Significant at 10 percent level of significance **Significant at 5 percent level of significance

The semi-log model was run for pulse area, production and yield of Bangladesh and the results shows that the models were significant for area, production and yield of pulse crop. The trend co-efficient of area, production and yield was positive. The positive sign of compound growth rate shows that area, production and yield of pulse was increased over the time. Annual percentage growth during 1969-74 to 200409 was increased at the rate of 2.6 percent in area, while production and yield increased per year at the rate of 3.2 percent and 0.6 percent respectively.

\subsection{Trend and Rate of Growth in Rape and Mustard of Bangladesh}

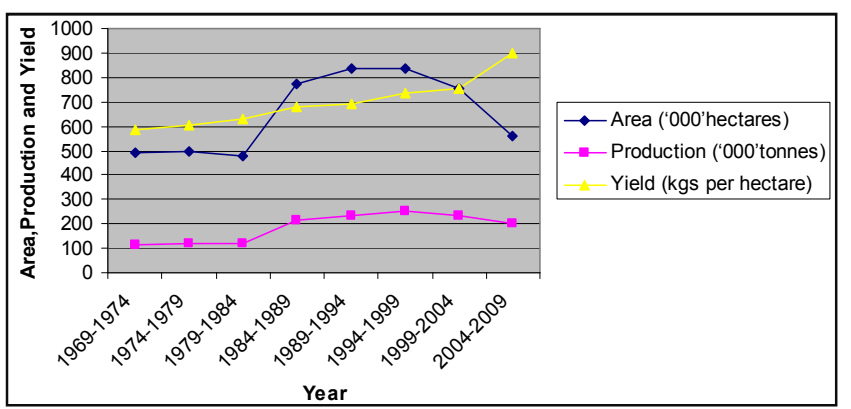

Source: Statistics department, Bangladesh Bank.

Figure 4. Trend in area, production and yield of rape and mustard in Bangladesh, 1969-2009.

Rape and mustard is an important crop of Bangladesh. In 1969-74, the area under rape and mustard was 488.40 thousand hectares which increased to 561.6 thousand hectares in 2004-09 and production increased from 115.60 thousand tons in 1969-74 to 203.80 thousand tons in 200409 , while the yield of rape and mustard increased from $584.63 \mathrm{~kg}$ per hectare to $896.34 \mathrm{~kg}$ per hectare during the same period.

The results of semi-log model for area, production and yield of rape and mustard were presented in table 4 . The results of F-statistic show that the models were significant for 
production and yield of rape and mustard whereas model for area was statistically non-significant. It was revealed from the table that trend co-efficient for rape and mustard area, production and yield is positive. The positive sign of compound growth rate shows that area, production and yield of rape and mustard was increasing at a rate of 1.21 percent, 2.33 percent and 1.11 percent per annum respectively.

Table 4. Trend and rate of growth in area, production and yield of rape and mustard in Bangladesh, 1969-2009.

\begin{tabular}{llll}
\hline Particulars & Area & Production & Yield \\
\hline F-statistic & $2.73^{\mathrm{NS}}$ & $12.39^{* *}$ & $80.60^{* * *}$ \\
Trend coefficient & 0.012 & 0.023 & 0.011 \\
t-statistic & $1.65^{\mathrm{NS}}$ & $3.52^{* *}$ & $8.98^{* * *}$ \\
Instantaneous growth rate (\%) & 1.20 & 2.30 & 1.10 \\
Compound growth rate (\%) & 1.21 & 2.33 & 1.11 \\
\hline
\end{tabular}

***Significant at 1 percent level of significance $* *$ Significant at 5 percent level of Significance and NS= Not significant.

\subsection{Trend and Rate of Growth in Jute of Bangladesh}

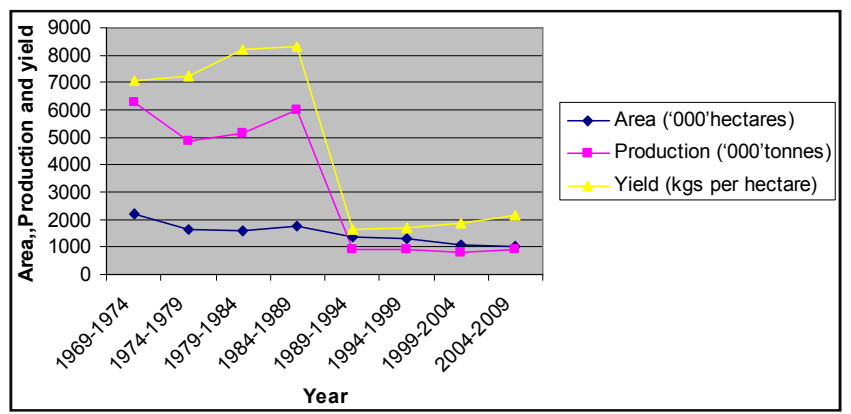

Source: Statistics department, Bangladesh Bank.

Figure 5. Trend in area, production and yield of jute in Bangladesh, 1969 2009.

The area under jute crop in Bangladesh was decreased from 2181 thousand hectares to 1024 thousand hectares during 1969 to 2009. The production of jute during the same period was also decreased from 6261 thousand tones to 885 thousand tones due to the corresponding decrease in area.

Table 5. Trend and rate of growth in area, production and yield of jute in Bangladesh, 1969-2009.

\begin{tabular}{llll}
\hline Particulars & Area & Production & Yield \\
\hline F-statistic & $49.48^{* * *}$ & $19.64 * * *$ & $11.55^{* *}$ \\
Trend coefficient & -0.020 & -0.071 & -0.051 \\
t-statistic & $-7.034 * * *$ & $-4.43^{* * *}$ & $-3.39 * *$ \\
Instantaneous growth rate (\%) & -2.0 & -7.10 & -5.1 \\
Compound growth rate (\%) & -2.0 & -7.43 & -5.23 \\
\hline
\end{tabular}

*Significant at 1 percent level of significance **Significant at 5 percent level of significance.

It was revealed from the table that trend co-efficient for jute production, yield and area was negative. The negative sign of compound growth rate shows that area, production and yield of jute crop was decreasing at a rate of 2.0 percent, 7.43 percent and 5.23 percent per annum.

\subsection{Trend and Rate of Growth in Sugarcane of Bangladesh}

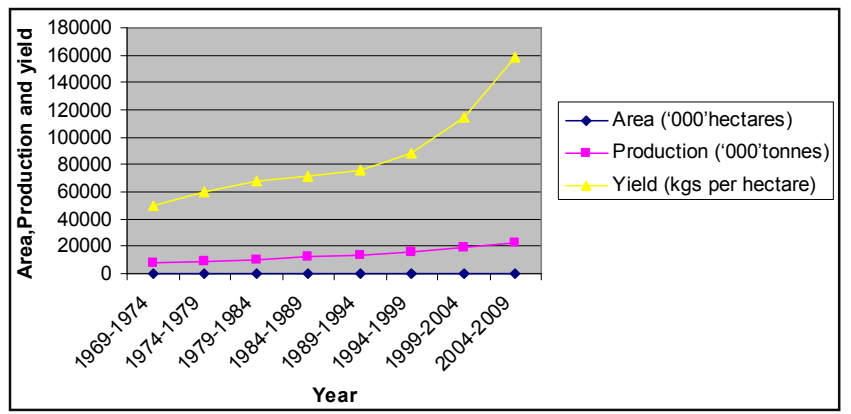

Source: Statistics department, Bangladesh Bank.

Figure 6. Trend in area, production and yield of sugarcane in Bangladesh, 1969-2009.

Sugarcane is an important cash crop of Bangladesh. Sugarcane production in Bangladesh has increased over time up to the year 2004-2009, whereas their yield also increased due to the corresponding increase in production. Figure 6 indicates that during 1969-74 the area under sugarcane in Bangladesh was 366.20 thousand hectares as compared to 353.60 thousand hectares sown during 2004-09, which shows that area of sugarcane crop decreased over the time.

Table 6. Trend and rate of growth in area, production and yield of sugarcane in Bangladesh, 1969-2009.

\begin{tabular}{llll}
\hline Particulars & Area & Production & Yield \\
\hline F-statistic & $0.361^{\mathrm{NS}}$ & $1058.92^{* * *}$ & $72.055^{* * *}$ \\
Trend coefficient & 0.002 & 0.031 & 0.029 \\
t-statistic & $0.601^{\mathrm{NS}}$ & $32.54^{* * *}$ & $8.49^{* * *}$ \\
Instantaneous growth rate (\%) & 0.20 & 3.10 & 2.90 \\
Compound growth rate (\%) & 0.20 & 3.15 & 2.94 \\
\hline
\end{tabular}

***Significant at 1 percent level of significance NS= Not significant.

The results of semi-log model for area, production and yield of sugarcane crop were presented in table 6 . The results of Fstatic show that the models were significant for production and yield of sugarcane crop whereas model for sugarcane area was statistically non-significant. It was revealed from the table 6 that trend co-efficient for area, production and yield of sugarcane crop was increasing at a rate of 0.20 percent, 3.15 percent and 2.94 percent per annum, respectively.

\subsection{Trend and Rate of Growth in Tea of Bangladesh}

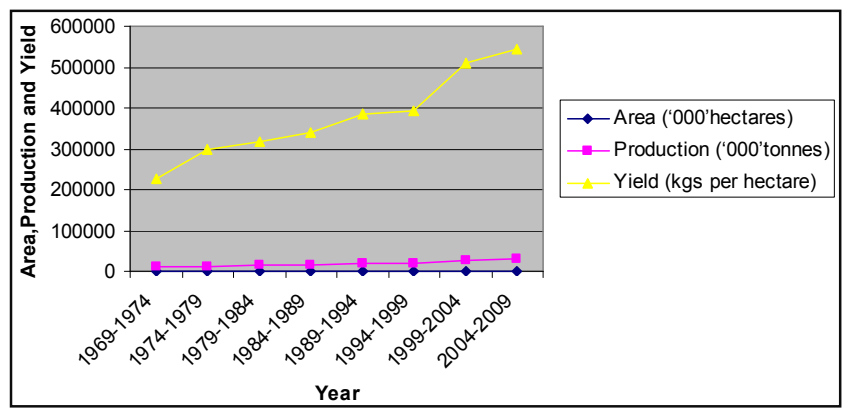

Source: Statistics department, Bangladesh Bank.

Figure 7. Trend in area, production and yield of tea in Bangladesh, 1969-2009. 
Figure 7 indicates that tea was planted in Bangladesh in 1969-74 on an area of 109.40 thousand hectares with production of 9954 thousand tones and yield $224738 \mathrm{~kg}$ per hectare. In the recent year 20044-09 the tea area, production and yield were increased to131.660 thousand hectares with an annual production of 289990 thousand tones and yield $544113 \mathrm{~kg}$ per hectare.

Table 7. Trend and rate of growth in area, production and yield of tea in Bangladesh, 1969-2009.

\begin{tabular}{llll}
\hline Particulars & Area & Production & Yield \\
\hline F-statistic & $55.54 * * *$ & $232.65 * * *$ & $127.73 * * *$ \\
Trend coefficient & 0.005 & 0.028 & 0.023 \\
t-statistic & $7.45^{* * *}$ & $15.25^{* * *}$ & $11.30 * * *$ \\
Instantaneous growth rate (\%) & 0.50 & 2.80 & 2.30 \\
Compound growth rate (\%) & 0.50 & 2.84 & 2.33 \\
\hline
\end{tabular}

***Significant at 1 percent level of significance.

The semi-log model was run for tea area, production and yield of Bangladesh and the results shows that the models were significant for area, production and yield of tea. The trend co-efficient of area, production and yield of tea was positive. The positive sign of compound growth rate shows that area, production and yield of tea was increased over the time. Annual percentage growth during 1969-74 to 2004-09 was increased at the rate of 0.5 percent in area, while production and yield increased per year at the rate of 2.8 percent and 2.30 percent, respectively. Whereas, the compound growth rate in area 0.50 percent, production 2.84 percent and yield 2.33 percent were calculated respectively. The data shows that area, production and yield of tea was increased over the time the reason is that more area was brought under tea production.

\section{Conclusion}

The compound growth rate as well as trend analysis indicated that the production of rice during 1969-74 to 200409 was increased due to the corresponding increase in per hectare yield of rice in Bangladesh. On the other hand, the trend analysis indicated that the production of jute during the same period was decreased due to the corresponding decrease in per hectare yield of jute in Bangladesh. The production of Wheat has increased due to the corresponding increase in area whereas per hectare yield of wheat has decreased over the time. In compare with wheat, the production of sugarcane was increased due to the corresponding increase in per hectare yield, whereas the area under sugarcane was decreased over the time. The results show that area, production and yield of tea, pulse, rape and mustard was increased over the time.

\section{Appendix}

Table A1. Trend and rate of growth in area, production and yield of rice in Bangladesh, 1969-2009.

\begin{tabular}{llll}
\hline Years & $\begin{array}{l}\text { Area } \\
\text { ('000'hectares) }\end{array}$ & $\begin{array}{l}\text { Production } \\
\text { ('000'tonnes) }\end{array}$ & $\begin{array}{l}\text { Yield (kgs } \\
\text { per hectare) }\end{array}$ \\
\hline $1969-1974$ & 24232 & 12203 & 1243.87 \\
$1974-1979$ & 24784 & 15867 & 1581.32 \\
$1979-1984$ & 25729 & 17009 & 1632.82 \\
$1984-1989$ & 25596 & 18406 & 1776.14 \\
$1989-1994$ & 25325 & 20417 & 1991.25 \\
$1994-1999$ & 24935 & 20737 & 2054.09 \\
$1999-2004$ & 26569 & 27037 & 2513.51 \\
$2004-2009$ & 26356 & 30438 & 2852.47 \\
\hline
\end{tabular}

Source: Statistics department, Bangladesh Bank.

Table A2. Trend in area, production and yield of wheat in Bangladesh, 19692009.

\begin{tabular}{llll}
\hline Years & $\begin{array}{l}\text { Area } \\
\text { ('000'hectares) }\end{array}$ & $\begin{array}{l}\text { Production } \\
\text { ('000'tonnes) }\end{array}$ & $\begin{array}{l}\text { Yield (kgs } \\
\text { per hectare) }\end{array}$ \\
\hline $1969-1974$ & 304.60 & 5677 & 46034.77 \\
$1974-1979$ & 444.40 & 7765 & 43158.30 \\
$1979-1984$ & 1287.00 & 8561 & 16430.20 \\
$1984-1989$ & 1462.20 & 8737 & 14758.85 \\
$1989-1994$ & 1491.40 & 10856 & 17979.29 \\
$1994-1999$ & 1845.80 & 10653 & 14255.56 \\
$1999-2004$ & 1826.20 & 12622 & 17071.70 \\
$2004-2009$ & 1097.00 & 10506 & 23655.26 \\
\hline
\end{tabular}

Source: Statistics department, Bangladesh Bank.

Table A3. Trend in area, production and yield of pulse in Bangladesh, 19692009.

\begin{tabular}{llll}
\hline Years & $\begin{array}{l}\text { Area } \\
\text { ('000'hectares) }\end{array}$ & $\begin{array}{l}\text { Production } \\
\text { ('000'tonnes) }\end{array}$ & $\begin{array}{l}\text { Yield (kgs per } \\
\text { hectare) }\end{array}$ \\
\hline $1969-1974$ & 212.4 & 61.0 & 709.37 \\
$1974-1979$ & 222.4 & 57.2 & 635.27 \\
$1979-1984$ & 219 & 55.8 & 629.34 \\
$1984-1989$ & 586.6 & 162.8 & 685.50 \\
$1989-1994$ & 654.2 & 189 & 713.59 \\
$1994-1999$ & 644.8 & 200.6 & 768.43 \\
$1999-2004$ & 512.8 & 154.2 & 742.73 \\
$2004-2009$ & 339.2 & 115.8 & 843.24 \\
\hline
\end{tabular}

Source: Statistics department, Bangladesh Bank.

Table A4. Trend in area, production and yield of rape and mastard in Bangladesh, 1969-2009.

\begin{tabular}{llll}
\hline Years & $\begin{array}{l}\text { Area } \\
\text { ('000'hectares) }\end{array}$ & $\begin{array}{l}\text { Production } \\
\text { ('000'tonnes) }\end{array}$ & $\begin{array}{l}\text { Yield (kgs per } \\
\text { hectare) }\end{array}$ \\
\hline $1969-1974$ & 488.4 & 115.6 & 584.63 \\
$1974-1979$ & 495.4 & 120.6 & 601.30 \\
$1979-1984$ & 476.2 & 120.8 & 626.58 \\
$1984-1989$ & 772.0 & 212.2 & 678.93 \\
$1989-1994$ & 836.4 & 234.2 & 691.62 \\
$1994-1999$ & 838.6 & 249.4 & 734.58 \\
$1999-2004$ & 754.2 & 229.8 & 752.59 \\
$2004-2009$ & 561.6 & 203.8 & 896.34 \\
\hline
\end{tabular}

Source: Statistics department, Bangladesh Bank. 
Table A5. Trend in area, production and yield of jute in Bangladesh, 19692009

\begin{tabular}{llll}
\hline Years & $\begin{array}{l}\text { Area } \\
\text { ('000'hectares) }\end{array}$ & $\begin{array}{l}\text { Production } \\
\text { ('000'tonnes) }\end{array}$ & $\begin{array}{l}\text { Yield (kgs per } \\
\text { hectare) }\end{array}$ \\
\hline $1969-1974$ & 2181.00 & 6261.20 & 7090.86 \\
$1974-1979$ & 1656.40 & 4873.60 & 7267.44 \\
$1979-1984$ & 1561.00 & 5175.60 & 8189.45 \\
$1984-1989$ & 1776.80 & 6005.80 & 8348.90 \\
$1989-1994$ & 1340.00 & 889.40 & 1639.42 \\
$1994-1999$ & 1275.40 & 891.00 & 1725.55 \\
$1999-2004$ & 1066.00 & 797.00 & 1846.71 \\
$2004-2009$ & 1024.00 & 885.20 & 2135.20 \\
\hline
\end{tabular}

Source: Statistics department, Bangladesh Bank.

Table A6. Trend in area, production and yield of sugarcane in Bangladesh, 1969-2009.

\begin{tabular}{llll}
\hline Years & $\begin{array}{l}\text { Area } \\
\text { ('000'hectares) }\end{array}$ & $\begin{array}{l}\text { Production } \\
\text { ('000'tonnes) }\end{array}$ & $\begin{array}{l}\text { Yield (kgs per } \\
\text { hectare) }\end{array}$ \\
\hline $1969-1974$ & 366.20 & 7388 & 49831.68 \\
$1974-1979$ & 365.80 & 8909 & 60156.45 \\
$1979-1984$ & 392.40 & 10732 & 67553.62 \\
$1984-1989$ & 412.00 & 11938 & 71570.05 \\
$1989-1994$ & 460.40 & 14094 & 75612.90 \\
$1994-1999$ & 434.60 & 15516 & 88183.43 \\
$1999-2004$ & 410.80 & 19060 & 114601.27 \\
$2004-2009$ & 353.60 & 22746 & 158887.50 \\
\hline
\end{tabular}

Source: Statistics department, Bangladesh Bank.

Table A7. Trend in area, production and yield of tea in Bangladesh, 19692009

\begin{tabular}{llll}
\hline Years & $\begin{array}{l}\text { Area } \\
\text { ('000'hectares) }\end{array}$ & $\begin{array}{l}\text { Production } \\
\text { ('000'tonnes) }\end{array}$ & $\begin{array}{l}\text { Yield (kgs per } \\
\text { hectare) }\end{array}$ \\
\hline $1969-1974$ & 109.40 & 9954 & 224738.39 \\
$1974-1979$ & 106.60 & 12800 & 296585.37 \\
$1979-1984$ & 109.60 & 14031 & 316209.58 \\
$1984-1989$ & 112.60 & 15454 & 338999.82 \\
$1989-1994$ & 117.80 & 18391 & 385617.74 \\
$1994-1999$ & 119.20 & 18913 & 391905.29 \\
$1999-2004$ & 122.80 & 25245 & 507778.09 \\
$2004-2009$ & 131.60 & 28990 & 544113.22 \\
\hline
\end{tabular}

Source: Statistics department, Bangladesh Bank.

\section{References}

[1] Basak, J. K. 2012, Real Sector: Agriculture, Growth or Contraction, Dhaka: Sharabon Prokashani.

[2] Bhuiyan, N. I., D. N. R. Paul and M. A. Jabber. 2002. Feeding the extra millions by 2025 Challenges for rice research and extension in Bangladesh, National Workshop on Rice Research and Extension in Bangladesh, Bangladesh Rice Research Institute, Gazipur, 29-3 January.

[3] N. Sarkar, S. K. Dutta, A. Majumdar, S. K. Biswas 'Trends in changing pattern of productivity of agricultural land in the District of Bardwan of West Beangal-A case study', International Journal of Innovative Research \& Studies, ISSN2319-9725.

[4] Rao, V. M., Nadkarni, M. V., \& Deshpande, R. S. (1980). Measurement of growth and fluctuations in crop output-an approach based on the concept of non-systematic component. Indian Journal of Agricultural Economics, 35 (2). 21-30.

[5] Recent Trends of Growth in Agriculture, Industry and Power. Bangladesh Economic Update, March 2014.

[6] Schultz, T. (1964): Transforming Traditional Agriculture, Yale University Press.

[7] S. Abid et al. 'Growth and Trend in Area, Production and Yield of Major Crops of Khyber Pakhtunkhwa, Pakistan', Asian Journal of Agriculture and Rural Development, 4 (2) 2014: 149-155.

[8] Sagar, V. (1980). Decomposition of Growth Trends and certain Related Issues. Indian Journal of Agricultural Economics. 35 (2), 42-59.

[9] Wiktor L. A., \& Travis. W. Manning. (1985). The measurement of growth rates from time series. Canadian J. of Agricultural Economics. 38 (2). 231-242.

[10] http://www.new-ag.info/en/country/profile.php?a=1834 dated: 07/11/2015.

[11] https://www.bb.org.bd/econdata/index.php. 